\title{
PENGARUH AMPAS TEH DAN AIR KELAPA MUDA TERHADAP PERTUMBUHAN DAN PRODUKTIVITAS TANAMAN SAWI (Brassica juncea L)
}

\author{
Monika Markus ${ }^{1}$, Amarullah Amarullah ${ }^{1}$ \\ ${ }^{1}$ Program Studi Agroteknologi, Fakultas Pertanian, Universitas Borneo Tarakan. \\ Jl. Amal Lama No. 1, Kota Tarakan, Kalimantan Utara, Indonesia. \\ Email: Monikamarkus27i@gmail.com
}

Received: 16 February 2019

Accepted: 20 April 2019

\begin{abstract}
The research was carried out in the agricultural field of the Faculty of Agriculture, University of Kalimantan Tarakan, the purpose of the study was to determine the effect of pulp and young coconut water on the growth and productivity of mustard plants. With the repetition of Random Group Design (RBD) 3 methods, the dose of tea pulp in Treatment 1 was $2 \mathrm{~kg}$, treatment 2 was $4 \mathrm{~kg}$, treatment 3 was $6 \mathrm{~kg}$, whereas young coconut water Treatment 1 was $50 \mathrm{ml}$, treatment 2 was $100 \mathrm{ml}$, treatment 3 A total of $150 \mathrm{ml}$. The results showed that AT conservation gave a significant difference to plant height at 7 days after planting and the number of leaves at 21 days after planting, while the AK treatment showed significant differences in leaf length of 21 days after planting and the longest root, weight and dry weight of mustard plants, combination of AT and AK treatment. on the number of leaves aged 21 HST.
\end{abstract}

Keywords: Tea Leaves, Young Coconut Water, Mustard (Brassica juncea L.)

\begin{abstract}
ABSTRAK
Penelitian dilakasanakan di lahan pertanian Fakultas pertanian Universitas Borneo Tarakan, Tujuan penelitian untuk mengetahui pengaruh ampas teh dan air kelapa muda terhadap pertumbuhan dan produktivitas tanaman sawi. Dengan metode Rancangan acak kelompok (RAK) 3 pengulangan, dosis ampas teh pada Perlakuan 1 sebanyak $2 \mathrm{~kg}$, perlakuan 2 sebanyak $4 \mathrm{~kg}$, perlakuan 3 sebanyak $6 \mathrm{~kg}$, sedangkan Air kelapa muda Perlakuan 1 sebanyak $50 \mathrm{ml}$, perlakuan2 sebanyak $100 \mathrm{ml}$, perlakuan 3 sebanyak $150 \mathrm{ml}$. Hasil penelitian menunjukkan perlakuan AT memeberikan pengaruh yang berbeda nyata terhadap tinggi tanaman umur 7 HST dan jumlah daun umur $21 \mathrm{HST}$, sedangkan Perlakuan AK memberikan pengaruh yang berbeda nyata terhadap panjang daun umur 21 HST dan Akar terpanjang, berat besah dan berat kering tanaman sawi, Kombinasi Perlakuan AT dan AK berpengaruh nyata terhadap jumlah daun umur $21 \mathrm{HST}$.
\end{abstract}

Kata kunci : Ampas Teh, Air Kelapa Muda, Sawi ( Brassica juncea L.).

\section{PENDAHULUAN}

Indonesia merupakan negara yang memiliki banyak kekayaan alam melimpah dan beragam, salah satunya berupa jenis sayuran hortikultura yang dibudidayakan. Menurut Haryanto (2015) sayur banyak mengandung serat yang dibutuhkan oleh tubuh manusia untuk melancarkan pencernaan dan dapat mencegah kanker.

Menurut Hamli (2015), salah satu jenis tanaman sayuran yang mudah dibudidayakan adalah sawi (Brassica juncea L.). Tanaman sawi merupakan tanaman semusim atau hortikultura, yang sering dimanfaatkan pada bagian daun atau bunganya sebagai bahan pangan. Sawi merupakan sayuran yang memilki kadar nutrisi yang lengkap. Menurut Haryanto (2003), nilai gizi yang terkandung dalam $100 \mathrm{~g}$ berat basah sawi yaitu vitamin A $0,09 \mathrm{mg}$, vitamin B $102 \mathrm{mg}$ dan vitamin C102 mg, Ca $220 \mathrm{mg}, \mathrm{P} 38 \mathrm{~g}, \mathrm{Fe} 2,9$ $\mathrm{g}$, protein $2,3 \mathrm{~g}$, lemak $0,3 \mathrm{~g}$, dan karbohidrat sebanyak $4 \mathrm{~g}$.

Sawi memerlukan nutrisi yang tepat untuk mendukung pertumbuhan dan perkembangannya, cara yang efektif yaitu dengan pemberian pupuk. Penggunaan pupuk anorganik memang dapat meningkatkan kandungan hara tanah, tetapi dalam penggunaannya dapat menimbulkan efek negatif. Penggunaan pupuk urea dengan dosis yang berlebihan dapat menyebabkan pencemaran nitrat tanah. Efektivitas penggunaan pupuk urea tidak bertahan lama karena penggunaan pupuk kimia secara terus menerus dapat menyebabkan 
perubahan struktur tanah, pemadatan tanah kandungan unsur hara tanah menurun dan tanah tercemar (Triyono 2013).

Salah satu upaya untuk mengurangi penggunaan pupuk anorganik yaitu dengan penggunaan pupuk organik baik cair maupun padat. Pupuk organik cair merupakan salah satu cara untuk mengatasi kekurangan bahan organik, karena mampu memperbaiki sifat fisik, kimia dan biologi tanah, dapat meningkatkan kualitas maupun kuantitas hasil tanaman serta mampu mengurangi penggunaan pupuk anorganik (Rehatta 2014).

Penggunaan media tanam yang tepat akan menentukan pertumbuhan bibit yang akan ditanam. Secara umum media tanam yang digunakan harus bersifat ringan, murah, mudah diperoleh, gembur dan subur. Sehingga memungkinkan pertumbuhan bibit yang optimal (Cahyo 2016). Media tanam dapat berasal dari beberapa bahan termasuk limbah ampas teh.

Ampas teh biasanya hanya dibuang setelah diseduh dan hanya menjadi limbah, ternyata dapat digunakan sebagai media campur tanah. Ampas teh dapat digunakan pada semua jenis tanaman, misalnya sayur, tanaman hias dan tanaman obat-obatan. Menurut Dwidjoseputra (1994), ampas teh dapat digunakan karena mengandung karbohidrat yang berperan untuk pembentukan klorofil pada daun yang mengalami pertumbuhan di tempat gelap.

Pertumbuhan tanaman sawi tidak hanya dipengaruhi media tanam untuk pertumbuhan, tetapi pemberian pupuk cair maupun struktur kerja pada tanaman juga perlu dilakukan. Salah satunya dengan penyiraman air kelapa muda, Air kelapa muda merupakan salah satu produk tanaman yang dapat dimanfaatkan untuk meningkatkan kesuburan dan pertumbuhan tanaman.

Menurut Dwijeseputro, Fatimah (1994) dan (2008) Air kelapa muda selain mengandung mineral juga mengandung sitokinin, fosfor, dan kinetin yang berfungsi mempergiat pembelahan sel serta pertumbuhan tunas dan akar tanaman.

\section{METODE PENELITIAN Waktu dan Tempat Penelitian}

Penelitian ini dilaksanakan di lahan Fakultas Pertanian Universitas Borneo Tarakan. Alat dan Bahan Penelitian

Parang, timbangan, gelas ukur, hand sprayer, gembor, ember, meteran, pulpen, buku, dan bahan yang digunakan adalah benih sawi Varietas TOSAKAN cap panah merah, ampas teh cap Melati dan ampas teh tjap, air kelapa muda, pupuk kandang kotoran ayam.

\section{Rancangnan Penelitian}

Penelitian ini menggunakan metode Rancangan Acak Kelompok (RAK), disusun secara faktorial yag terdiri atas dua faktor, faktor pertama yaitu penggunaan ampas teh sebagai campuran media tanam sebanyak 3 perlakuan yaitu Ampas Teh 2 kg/bedeng, dan Ampas Teh 4 $\mathrm{kg} /$ bedeng, dan Ampas Teh $6 \mathrm{~kg} /$ bedeng, dan Faktor kedua yaitu Pengaplikasian air kelapa muda dengan 3 perlakuan yaitu Air Kelapa Muda 50ml/lt, Air Kelapa Muda 100ml/lt, Air Kelapa Muda $150 \mathrm{ml} / \mathrm{lt}$. Dan pengulangan sebanyak 3 kali. Adapun Layout penelitian dapat dilihat pada lampiran. Jenis ampas teh yang digunakan pada penelitian ini yaitu ampas teh bunga melati dan ampas teh tjap. Pada penelitian ini ampas yang digunakan sebanyak $108 \mathrm{~kg}$.

\section{Persiapan bedeng untuk persemaian}

Bedengan seluas $2 \mathrm{~m}^{2}$ dibersihkan dan dicangkul untuk menyemai benih sawi di lahan pertanian Fakultas Pertanian Universitas Borneo Tarakan.

\section{Persiapan media tanam sawi}

Lahan dibersihkan kemudian dicangkul dan digemburkan, lahan yang sudah digemburkan dibentuk petakan dengan 3 blok sebanyak 27 petak untuk setiap bedengan masing-masing berukur $120 \mathrm{~cm}$ x $100 \mathrm{~cm}$.

\section{Persiapan bahan}

Limbah ampas teh disiapkan untuk dicampur dengan tanah sebagai bahan campur media tanam. Setelah penyemaian dilakukan pembuatan bedeng untuk kegiatan penanaman sawi dapat dilaksanakan. Selain ampas teh yang digunakan pada penelitian ini. juga Air Kelapa Muda. Bahan utama pada penelitian yaitu benih sawi Varietas TOSAKAN cap Panah Merah.

\section{Penanaman}

Bibit tanaman sawi dapat dipindah/ditanam di bedengan yang sudah disiapkan dengan jarak tanam masing masing 20 $\mathrm{cm} \times 30 \mathrm{~cm}$ setelah berumur 10 sampai dengan 14 hari penanaman sawi dilakukan saat sore hari. Penyiraman

Tanaman sawi disiram sesuai kebutuhan air tanaman sawi. Sawi disiram pada pagi hari dan sore hari untuk mengantisipasi kelayuan sawi dan mempercepat pertumbuhan sawi.

\section{Pengendalian Organisme Pengganggu Tanaman (OPT) tanaman sawi}

Pengendalian OPT pada tanaman sawi dapat dilakukan setelah mengidentifikasi OPT yang menyerang tanaman agar bisa mengetahui jenis OPT tersebut dan bisa mengetahui cara 
pengendalian untuk pengendalian OPT baik itu pengendalian dengan biopestisida maupun pestisida sintetis. jenis OPT yang paling umum menyerang tanaman sawi salah satunya pemakan daun tanaman yaitu ulat grayak.

\section{Parameter pengamatan}

Pada penelitian ini memiliki parameter pertumbuhan dan parameter produktivitas, parameter pertumbuhan meliputi tinggi tanaman, jumlah daun, panjang, lebar daun, diameter batang, Sedangkan untuk parameter produksitivitasnya meliputi berat basah sampel tanaman, berat kering tanaman sawi, jumlah akar, dan akar terpanjang tanaman sawi.

\section{Parameter Pertumbuhan}

\section{Tinggi tanaman sawi}

Tinggi tanaman diukur menggunakan penggaris dengan cara mengukur dari pangkal batang tanaman sampai pada ujung daun yang paling tinggi, untuk pengamatan pertama tanaman sawi tingginya diukur pada umur 1 minggu setelah tanam.

\section{Jumlah Daun Sawi}

Pengamatan pertumbuhan juga meliputi perhitungan banyaknya jumlah daun sawi yang pengamatannya dilakukan setiap minggu. Dari perhitungan jumlah daun pada sampel tanaman sawi dapat diketahui dampak perbandingan dari perlakuan dua faktor. jumlah daun dihitung dengan cara menghitung banyaknya daun yang telah terbuka sempurna setelah tanaman berumur 1 minggu setelah tanam.

\section{Panjang daun tanaman sawi}

Pengamatan daun terpanjang dilaksanakan setiap minggu pada sampel tanaman yang telah ditentukan kemudian pengukuran panjang daun menggunakan penggaris, yang diukur secara manual.

\section{Lebar Daun Tanaman Sawi}

Pengamatan lebar daun dilaksanakan setelah pengamatan panjang daun, lebar daun tanaman sawi juga diukur secara manual dan diamati setiap minggu.

\section{Diameter Batang}

Diameter batang diamati setiap minggu dengan menggunakan jangka sorong, pada pangkal batang tanaman sawi.

\section{Parameter Produktivitas Tanaman Sawi Berat basah/kering tanaman}

Perhitungan berat basah/kering dilakukan pada setiap perlakuan dan mewakili satu sampel tanaman yang palig bagus. Parameter dilakukan setelah panen, untuk berat besah tanaman diketahui dengan menimbang menggunkan timbangan analitik, yang kemudian dilakukan pengovenan sampel tanaman selama 3 hari dengan suhu $80^{\circ} \mathrm{C}$ untuk mengetahui bobot kering pada sampel tanaman.

\section{Jumlah akar}

Parameter produktivitas tanaman juga meliputi jumlah akar tanaman, pengamatan jumlah akar dilaksanankan setelah panen. jumlah akar yang dihitung hanya akar utama saja secara manua

\section{Akar terpanjang}

Parameter Panjang akar tanaman diukur menggunakan penggaris, akar yang diukur ialah akar yang terpanjang pada sampel sawi, pengamatan dilakukan setelah panen.

\section{Analisis Data}

Analisis data dalam penelitian ini menggunakan Anova dengan tingkat kepercayaan 95\%, Anova digunakan untuk mengetahui apakah perlakuan pada penelitian ada perbedaan atau tidak terhadap hasil tanaman yang ditanam jika data dari penelitian berbeda nyata. Tapi jika data yang diperoleh tingkat perbedaan kecil maka digunakan DMRT (Duncan's Multiple Range Test).

\section{HASIL DAN PEMBAHASAN}

\section{Hasil}

Hasil yang diamati dalam penelitian ini adalah paramater pertumbuhan tanaman yang meliputi tinggi tanaman, jumlah daun, panjang daun lebar dan lebar daun serta diameter batang, dan parameter produktivitas tanaman yang meliputi berat basah jumlah akar, akar terpanjang, berat kering.

\section{Tinggi tanaman}

Tabel 1. Hubungan perlakuan pada tinggi tanaman

\begin{tabular}{cccc}
\hline \multirow{2}{*}{$\begin{array}{c}\text { Kombinasi } \\
\text { Perlakuan }\end{array}$} & \multicolumn{3}{c}{$\begin{array}{c}\text { Tinggi Tanaman } \\
(\mathrm{cm})\end{array}$} \\
\cline { 2 - 4 } & $7 \mathrm{HST}$ & $14 \mathrm{HST}$ & $21 \mathrm{HST}$ \\
\hline AT1AK1 & $11,78 \mathrm{~d}$ & 21,51 & 32,65 \\
AT1AK2 & $12,41 \mathrm{~b}$ & 19,28 & 33,28 \\
AT1AK3 & $11,45 \mathrm{~g}$ & 19,87 & 34,14 \\
AT2AK1 & $11,67 \mathrm{e}$ & 22,91 & 34,06 \\
AT2AK2 & $13,69 \mathrm{a}$ & 19,38 & 32,57 \\
AT2AK3 & $12,00 \mathrm{c}$ & 20,14 & 30,35 \\
AT3AK1 & $11,55 \mathrm{f}$ & 19,2 & 32,78 \\
AT3AK2 & $10,66 \mathrm{i}$ & 20,96 & 32,7 \\
AT3AK3 & $10,87 \mathrm{~h}$ & 20,38 & 30,32 \\
KK & 100,17 & 172,91 & 214,27 \\
Uji F & $0,498^{\text {tn }}$ & $0,263^{\text {tn }}$ & $0,19^{\text {tn }}$ \\
Uji F AT & 0,96 & & \\
\hline
\end{tabular}

Perlakuan faktor tunggal AT memberikan pengaruh berbeda nyata pada tinggi tanaman pada umur 7 HST. Hasil analisis sidik ragam 
tinggi tanaman menunjukan bahwa perlakuan kombinasi Ampas teh dengan Air kelapa muda tidak memberikan pengaruh nyata terhadap tinggi tanaman sawi dari umur 7, 14, 21 Hst. Tetapi perlakuan AT pada umur 7 HST

\begin{tabular}{cccc}
\hline $\begin{array}{c}\text { Kombinasi } \\
\text { Perlakuan }\end{array}$ & \multicolumn{3}{c}{$\begin{array}{c}\text { Panjang Daun } \\
(\mathrm{Cm})\end{array}$} \\
\cline { 2 - 4 } & $7 \mathrm{HST}$ & $14 \mathrm{HST}$ & $21 \mathrm{HST}$ \\
\hline AT1AK1 & 7,33 & 13,67 & $20,00 \mathrm{a}$ \\
AT1AK2 & 7,33 & 12,67 & $14,33 \mathrm{e}$ \\
AT1AK3 & 6,67 & 12,00 & $18,67 \mathrm{c}$ \\
AT2AK1 & 7,00 & 13,67 & $19,33 \mathrm{~b}$ \\
AT2AK2 & 7,33 & 13,67 & $18,67 \mathrm{c}$ \\
AT2AK3 & 6,67 & 12,67 & $19,33 \mathrm{~b}$ \\
AT3AK1 & 6,67 & 12,00 & $19,33 \mathrm{~b}$ \\
AT3AK2 & 6,33 & 12,33 & $18,67 \mathrm{c}$ \\
AT3AK3 & 7,00 & 12,67 & $18,00 \mathrm{~d}$ \\
KK & 63,55 & 90,2 & 158,49 \\
Uji F AK & $0,14^{\text {tn }}$ & 0,30 th & 1,28 \\
SDT & & & 4,15 \\
DMRT & & & 0,2 \\
\hline
\end{tabular}

memberikan pengaruh yang berbeda nyata. Perlakuan terbaik pada tinggi tanaman terdapat pada Kombinasi perlakuan AT1AK3 (Ampas teh dengan takaran $2 \mathrm{~kg}$ dan Air Kelapa $150 \mathrm{ml}$ ) mampu meningkatkan tinggi tanaman setinggi $34,14 \mathrm{~cm}$ pada 21 Hst lebih tinggi dari perlakuan lainnya.

\section{Jumlah Daun}

Perlakuan AT dan Interaksi memberikan pengaruh yang berbeda nyata pada jumlah daun tanaman sawi pada umur 21 HST.

Hasil analisis sidik ragam jumlah daun menunjukkan bahwa perlakuan Ampas teh yang dikombinasikan dengan air kelapa muda tidak memberikan pengaruh nyata terhadap jumlah daun sawi dari umur 7, 14 HST. Namun pada umur 21 HST Perlakuan Ampas teh dan interaksi memberikan pengaruh nyata pada banyaknya jumlah daun tanaman sawi. Kombinasi perlakuan terbaik adalah AT1AK2 (Ampas teh dengan takaran $2 \mathrm{~kg}$, air kelapa muda $100 \mathrm{ml}$ ). Mampu memperbanyak jumlah daun tanaman sawi sebanyak 7 helai daun pada umur $21 \mathrm{HST}$, begitu juga dengan kombinasi perlakuan AT2AK2 (Ampas teh dengan takaran $4 \mathrm{~kg}$ dan air kelapa muda sebanyak $100 \mathrm{ml}$ ) dapat memperbanyak jumlah daun tanaman sawi pada umur 21 HST.

Tabel 2. Hubungan perlakuan pada jumlah daun

\begin{tabular}{cccc}
\hline & \multicolumn{3}{c}{ Jumlah Daun } \\
\hline Kombinasi \\
Perlakuan & \multicolumn{3}{c}{$14 \mathrm{HST}$} \\
\cline { 2 - 4 } & $7 \mathrm{HST}$ & 4,33 & $6,67 \mathrm{bST}$ \\
\hline AT1AK1 & 3,67 & 6,00 & $7,00 \mathrm{a}$ \\
AT1AK2 & 3,67 & 4,00 & $6,67 \mathrm{~b}$ \\
AT1AK3 & 3,00 & 4,33 & $5,67 \mathrm{c}$ \\
AT2AK1 & 3,67 & 4,33 & $7,00 \mathrm{a}$ \\
AT2AK2 & 4,33 & 3,67 & $5,67 \mathrm{c}$ \\
AT2AK3 & 3,67 & 4,00 & $5,00 \mathrm{e}$ \\
AT3AK1 & 3,33 & 4,00 & $5,00 \mathrm{e}$ \\
AT3AK2 & 4,00 & 4,33 & $5,33 \mathrm{~d}$ \\
AT3AK3 & 3,67 & 96,82 & 61,24 \\
KK & 39,52 & $0,22^{\text {th }}$ & $3,3 / 2,17$ \\
Uji F AT/Interaksi & $0,51^{\text {th }}$ & & 1,33 \\
SDT & & & 0,066 \\
DMRT & & & \\
\hline
\end{tabular}

\section{Panjang Daun}

Perlakuan AK memberikan pengaruh yang berbeda nyata terhadap panjang daun umur 21 HST.

Tabel 3. Hubungan perlakuan pada panjang daun Hasil analisis sidik ragam panjang daun menunjukkan bahwa Kombinasi perlakuan tidak memberikan pengaruh yang berbeda nyata terhadap panjang daun sawi dari umur 7, 14, 21 HST, tetapi perlakuan AK memberikan pengaruh yang berbeda nyata pada umur 21 HST. Berdasarkan data pada tabel 5 Kombinasi perlakuan yang terbaik adalah AT1AK21 (Ampas teh dengan takaran $2 \mathrm{~kg}$, air kelapa muda $50 \mathrm{ml}$ ) Mampu mempengaruhi panjang daun tanaman sawi pada umur 21 HST, dengan angka $20 \mathrm{~cm}$.

\section{Lebar Daun}

Tabel 4. Hubungan perlakuan pada lebar daun

\begin{tabular}{cccc}
\hline $\begin{array}{c}\text { Kombinasi } \\
\text { Perlakuan }\end{array}$ & \multicolumn{3}{c}{$\begin{array}{c}\text { Lebar Daun } \\
(\mathrm{Cm})\end{array}$} \\
\cline { 2 - 4 } & $7 \mathrm{HST}$ & $14 \mathrm{HST}$ & $21 \mathrm{HST}$ \\
\hline AT1AK1 & 4,67 & $6,67 \mathrm{~d}$ & $11,33 \mathrm{a}$ \\
AT1AK2 & 4,00 & $6,67 \mathrm{~d}$ & $9,00 \mathrm{~b}$ \\
AT1AK3 & 4,00 & $6,33 \mathrm{e}$ & $8,67 \mathrm{c}$ \\
AT2AK1 & 4,00 & $7,00 \mathrm{c}$ & $8,33 \mathrm{e}$ \\
AT2AK2 & 4,67 & $7,33 \mathrm{~b}$ & $9,00 \mathrm{~b}$ \\
AT2AK3 & 4,33 & $7,33 \mathrm{~b}$ & $8,67 \mathrm{c}$ \\
AT3AK1 & 4,00 & $7,00 \mathrm{c}$ & $9,00 \mathrm{~b}$ \\
AT3AK2 & 4,33 & $7,67 \mathrm{a}$ & $9,00 \mathrm{~b}$ \\
AT3AK3 & 4,33 & $6,33 \mathrm{e}$ & $8,00 \mathrm{~d}$ \\
KK & 41,8 & 78,72 & 37,79 \\
Uji F AT/AK & $0,23^{\text {th }}$ & $2,5^{\text {th }}$ & $4,66 / 4,32$ \\
SDT & & & 3,4 \\
DMRT & & & 0,88 \\
\hline
\end{tabular}


Perlakuan AT dan AK memberikan pengaruh yang berbeda nyata pada lebar daun tanaman sawi umur 21 HST

Hasil analisis sidik ragam Lebar daun menunjukkan bahwa Perlakuan AT dan AK memberikan pengaruh yang berbeda nyata pada umur 21 HST, Kombinasi perlakuan terbaik ditunjukkan pada AT1AK1 (Ampas Teh $2 \mathrm{~kg}$, Air Kelapa Muda $50 \mathrm{ml}$ ) pada umur $21 \mathrm{HST}$ dengan angka $11,33 \mathrm{~cm}$.

\section{Diameter Batang}

Tabel 5. Hubungan perlakuan pada diameter batang

\begin{tabular}{cccc}
\hline Kombinasi & \multicolumn{3}{c}{$\begin{array}{c}\text { Diameter Batang } \\
\text { Cm }\end{array}$} \\
\cline { 2 - 4 } Perlakuan & 7 HST & 14 HST & 21 HST \\
\hline AT1AK1 & 0,33 & 0,68 & 1,83 \\
AT1AK2 & 0,24 & 0,78 & 1,53 \\
AT1AK3 & 0,31 & 0,6 & 1,62 \\
AT2AK1 & 0,29 & 0,69 & 1,51 \\
AT2AK2 & 0,33 & 0,71 & 1,76 \\
AT2AK3 & 0,28 & 0,72 & 1,59 \\
AT3AK1 & 0,26 & 0,67 & 1,7 \\
AT3AK2 & 0,24 & 0,74 & 1,7 \\
AT3AK3 & 0,29 & 0,67 & 1,41 \\
KK & 2,43 & 4,25 & 11,98 \\
Uji F & $0,59^{\text {tn }}$ & $0,35^{\text {tn }}$ & $0,36^{\text {tn }}$ \\
\hline
\end{tabular}

Perlakuan AT dan AK tidak memberikan pengaruh yang berbeda nyata.

Hasil analisis sidik ragam diameter menunjukan bahwa Kombinasi Perlakuan Ampas teh dan Air Kelapa Muda tidak memberikan pengaruh yang berbeda nyata, Perlakuan kombinasi terbaik ditunjukkan pada Kombinasi Perlakuan AT1AK1 pada umur 21 HST (Ampas teh $2 \mathrm{~kg}$, Air Kelapa muda $50 \mathrm{ml}$ ) dengan angka $1,83 \mathrm{~cm}$.

\section{Data Produktivitas Tanaman Sawi}

Tabel 6. Data produktivitas tanaman sawi

\begin{tabular}{ccccc}
\hline $\begin{array}{c}\text { Kombinasi } \\
\text { Perlakuan }\end{array}$ & $\begin{array}{c}\text { Berat } \\
\text { basah }(\mathrm{g})\end{array}$ & Jumlah akar & $\begin{array}{c}\text { Akar } \\
\text { terpanjang(cm) }\end{array}$ & $\begin{array}{c}\text { Berat } \\
\text { kering(g) }\end{array}$ \\
\hline AT1AK1 & $98,50 \mathrm{~g}$ & 17,55 & $11,55 \mathrm{f}$ & $8,49 \mathrm{~h}$ \\
AT1AK2 & $145,47 \mathrm{~b}$ & 16,22 & $13,33 \mathrm{e}$ & $11,37 \mathrm{~b}$ \\
AT1AK3 & $119,87 \mathrm{f}$ & 14,45 & $14,78 \mathrm{c}$ & $11,08 \mathrm{c}$ \\
AT2AK1 & $130,70 \mathrm{c}$ & 13,56 & $11,33 \mathrm{~g}$ & $8,77 \mathrm{~g}$ \\
AT2AK2 & $121,87 \mathrm{e}$ & 13,67 & $10,67 \mathrm{i}$ & $10,43 \mathrm{e}$ \\
AT2AK3 & $99,37 \mathrm{~h}$ & 14,89 & $15,22 \mathrm{~b}$ & $9,45 \mathrm{f}$ \\
AT3AK1 & $99,37 \mathrm{~h}$ & 16,22 & $10,78 \mathrm{~h}$ & $8,42 \mathrm{i}$ \\
AT3AK2 & $166,70 \mathrm{a}$ & 20,67 & $15,89, \mathrm{a}$ & $12,99 \mathrm{a}$ \\
AT3AK3 & $129,71 \mathrm{~d}$ & 14,56 & $14,11 \mathrm{~d}$ & $10,52 \mathrm{~d}$ \\
KK & 2625,02 & 279,7 & 233,05 & 202,62 \\
Uji & 1,07 & $0,51^{\text {th }}$ & 1,50 & 1,011 \\
SDT & 1,33 & & 1,33 & 1,33 \\
DMRT & 0,067 & & 0,067 & 0,067 \\
\hline
\end{tabular}

Perlakuan AK memberikan Pengaruh yang berbeda nyata pada berat basah tanaman, berat kering tanaman, dan Akar terpanjang pada tanaman. Hasil analisis sidik ragam produktivitas menunjukkan bahwa Perlakuan AK memberikan pengaruh yang berbeda nyata pada Berat basah tanaman, akar terpanjang tanaman dan juga berat kering tanaman sawi, tetapi tidak memberikan pengaruh yang berbeda nyata pada jumlah akar tanaman. Kombinasi perlakuan terbaik pada berat basah ditunjukkan pada AT3AK2 (Ampas teh $6 \mathrm{~kg}$ Air kelapa muda $100 \mathrm{ml}$ ) dengan angka $166,70 \mathrm{~g}$, begitu juga pada Hasil analisis jumlah akar, akar terpanjang dan berat kering tanaman perlakuan kombinasi terbaik ditunjukkan pada AT3AK2, akar terpanjang dengan angka 15,89 $\mathrm{cm}$, dan berat keering tanaman dengan angka $12,99 \mathrm{~g}$, dan jumlah akar dengan angka 20,67.

\section{Pembahasan}

Pemberian Ampas teh pada tanaman sawi dapat menigkatkan pertumbuhan dan produktivitas tanaman sawi begitu juga dengan Pemberian air kelapa muda, Ampas teh berperan penting bagi tanaman sebagai penyedia unsur hara pada tanah dengan cara dekomposisi (Nadya 2008).

Air kelapa muda memiliki peran yang sama dengan ampas teh sebagai unsur hara untuk tanaman, tetapi jumlah kandungan masingmasing unsur hara berbeda - beda, jumlah $\mathrm{N}$ pada ampas teh ialah $0,4 \%$, jumlah $P$ pada ampas teh ialah $0,1 \%$, dan jumlah $\mathrm{K}$ ialah $0,2 \%$, sedangkan jumlah $\mathrm{N}$ pada air kelapa muda ialah $0,05 \%$, jumlah P pada air kelapa muda ialah $0,8 \%$, dan jumlah K pada air kelapa muda ialah $0,15 \%$ (Ria 2012).

Menurut Andi Kurniawan (2017) Tanaman perlu melakukan proses fisiologis secara maksiamal yang meliputi Fotosintesis, respirasi dan transpirasi bahkan pembentukan karbohidrat dan mineral pada tanaman, dengan demikian perlu memberikan berbagai unsur hara untuk proses fisiologis tanaman, Ampas teh dan air kelapa muda mengandung beberapa unsur hara makro dan mikro yang dapat membantu proses fisiologis pada tanaman, Pada ampas teh dan air kelapa muda terdapat unsur N P K, Unsur $\mathrm{N}$ berperan untuk mempercepat pertumbuhan vegetatif daun tanaman, unsur $P$ berperan untuk merangsang pertumbuhan tinggi, unsur $\mathrm{K}$ berperan untuk meningkatkan proses fotosintesis dan membantu sistem perakaran tanaman serta memperkokoh batang tanaman.

Hasil pengamatan pertumbuhan tanaman sawi dari umur 7, 14, 21 HST menunjukkan 
meningkatnya angka pertumbuhan, baik pada tinggi tanaman, jumlah daun, panjang daun, lebar daun dan diameter batang, dan hasil produktivitas tanaman sawi menunjukkan bahwa hasil produksi tanaman sawi diatas angka ratarata pada umumnya.

Pada umumnya berat basah Tanaman sawi hanya mencapai 80,50 g pertanaman (Zuchrotus 2017), sedangkan penelitian ini menunjukkan bahwa berat basah terbaik mencapai $166,70 \mathrm{~g}$ pertanaman. Secara statistik Data yang diperoleh tidak keseluruhan kombinasi perlakuan yang memberikan pengaruh yang berbeda nyata, tetapi secara fisiologis tanaman menunjukkan peningkatan pertumbuhan dari umur 7 - $21 \mathrm{HST}$.

Pertumbuhan tanaman yang normal memerlukan unsur hara yang seimbang dengan perbandingan dosis yang tepat, apabila komponen tersebut cukup dan seimbang maka proses pembelahan sel akan berlangsung cepat dan meningkatkan pertumbuhan tanaman (Sopardi 2015).

Penggunaan dosis ampas teh Yang tepat berpengaruh baik bagi pertumbuhan tanaman sawi, dosis ampas teh yang tepat adalah $400 \mathrm{~g}-$ $900 \mathrm{~g} /$ bedeng yang luasnya $100 \times 120 \mathrm{~cm}^{2}$ (Fatimah 2006). Pada penelitian yang telah dilaksanakan terdiri dari tiga taraf untuk perlakuan 1 ampas teh yang digunakan sebanyak $2 \mathrm{~kg}$, perlakuan 2 sebanyak $4 \mathrm{~kg}$, perlakuan 3 sebanyak $6 \mathrm{~kg}$, Hasil pengamatan pertumbuhan tanaman menunjukkan bahwa perlakuan ampas teh terbaik adalah perlakuan 1 dengan dosis $2 \mathrm{~kg}$.

Penggunaan air kelapa muda dapat meningkatkan pertumbuhan vegetatif tanaman sawi, cairan endospern pada buah kelapa mengandung senyawa-senyawa biologi yang aktif (Winarto et al. 2015). Hasil pengamatan pertumbuhan tanaman sawi menunjukkan manfaat air kelapa muda bagi pertumbuhan vegetatif tanaman setelah diamati tanaman mengalami peningkatan secara fisiologis tanaman sawi nampak subur dan segar tidak seperti pada tanaman sawi yang biasanya dibudidayakan oleh para petani yang belum memanfaatkan air kelapa muda, tidak hanya pertumbuhan tanaman sawi yang menunjukkan dampak positif dari penggunaan air kelapa muda tetapi juga produktivitas tanaman sawi menunjukkan dampak posiif penggunaan air kelapa muda.

Banyak nilai positif yang didapat dari penggunaan air kelapa muda yang dimanfaatkan bagi tanaman budidaya tak hanya terkandung unsur hara ataupun senyawa-senyawa biologi tetapi air kelapa muda juga mangandung komposisi kimia seperti mineral, vitamin, gula, asam amino, dan fithormon yang memililki efek baik bagi pertumbuhan tanaman sawi, dan juga tanaman yang dihasilkan aman untuk dikonsumsi (Agambodi, Wardana 2009).

Savitri, Djammhuri (2005), sidik (2011) air kelapa muda juga mengandung ZPT seperti Auksin, Giberelin, Sitokinin, dimana manfaat auksin adalah membantu Dalam mempercepat pertumbuhan batang tanaman, sedangkan manfaat dari giberelin selain mempercepat pertumbuhan tanaman sawi giberelin juga berperan penting bagi akar tanaman, dan fungsi dari sitokinin yaitu membantu menghambat penuaan yang terjadai pada daun sebelum waktunya.

Penggunaan dosis air kelapa muda dengan tepat memberikan pengaruh yang baik bagi tanaman budidaya, konsentrasi $250 \mathrm{ml} /$ bedeng dan $200 \mathrm{ml}$ / bedeng dapat memberikan pengaruh yang berbeda nyata. (Syahid 2012) Penggunaan air kelapa muda pada penelitian ini terdiri dari 3 perlakuan yang berbeda-beda, perlakuan 1 digunakan air kelapa muda sebanyak 50 $\mathrm{ml} /$ bedeng, perlakuan 2 digunakan air kelapa muda dengan dosis $100 \mathrm{ml} /$ bedeng, sedangkan perlakuan 3 digunakan dosis $150 \mathrm{ml} / \mathrm{bedeng}$. Dosis air kelapa muda yang terbaik bagi pertumbuhan tanaman sawi yaitu daengan dosis $150 \mathrm{ml} /$ bedeng.

Kombinasi Perlakuan pada penelitian memberikan pengaruh yang berbeda nyata pada analisis sidik ragam jumlah daun pada umur 21 HST dengan angka f hitung 2,17 $\geq 0,05.9$ yang artinya dalam data statistik tingkat kepercayaan pada sidik ragam jumlah daun umur 21 HST ialah $95 \%$.

\section{KESIMPULAN}

Berdasarkan penelitian yang telah dilakukan dapat disimpulkan bahwa, perlakuan Ampas Teh (AT) memberikan pengaruh terhadap pertumbuhan tinggi tanaman pada umur (7 HST), dan jumlah daun umur (21 HST), sedangkan Air Kelapa Muda (AK) memberikan pengaruh yang berbeda nyata terhadap panjang daun umur (21 HST), AK juga berpengaruh nyata pada akar terpanjang, berat basah, dan berat kering (umur 22 HST/Panen). Kombinasi Perlakuan AT dan AK berpengaruh nyata terhadap jumlah daun (Umur 21 HST). Kombinasi Perlakuan AT3AK2 merupakan perlakuan yang terbaik pada data produktivitas tanaman sawi 


\section{DAFTAR PUSTAKA}

Abidin Z. 2014. Dasar-Dasar Pengetahuan Tentang Zat Pengatur Tumbuh. Angkasa Bandung.

Agampodi VA, Jayawardena B. 2009. Effect of Coconut (Cocos nucifera L.) Water Extracts on Adventitious Root Development in Vegetative Propagation of Dracaena purplecompacta L. Acta. Physiol. Plant, 31: $279-284$.

Andi Kurniawan. 2007. Jurnal Produksi Tanaman Dosis dan Frekuensi Pupuk dan serapan N dan pertumbuhan sawi (Brassica junea L). Pada etinsol jln Agritek. 17 (5): 102-109.

Arini LDD, Suranto, E Mahajoeno. 2013. Studi Morfologi dan Anatomi Tanaman Capsicum Annum $\mathrm{L}$ terinfeksi virus di daerah Surakarta 1 (1) :45 - 54.

Aswani RMP, Yufdi. 2012. Pengaruh Air Kelapa Terhadap Pertumbuhan Stek Panili Pembudidaya Litri Puslitbangtri. Bogor. 15(2): $78-83$.

Cahyono, Bambang. 2003. Teknik Strategi Budidaya Tanaman Sawi Hijau Yogyakarta Yayasan Nusantara.

Djamhuri E. 2011 Pemanfaatan air kelapa untuk meningkatkan stek pucuk melati tembaga (Shore Leprola Miq), jurnal silvikultur tropika. 2 (1): 5 8.

Erawan DY, Bahrun. 2013. Pertumbuhan Dan Hasil Tanaman Sawi (Brassica Junea L.) Pada Berbagai Dosis Pupuk Urea Jurnal Agroteknos. 3 (1): 19 25.

Erfa dkk. 2012.Pengaruh Formulasi Media dan Konsentrasi Air Kelapa muda Pertumbuhan Protokorm Angrek Phalaenopsis in vitro. Jurnal Penelitian Pertanian Terapan, 12 (3) :167-174.

Hartatik, Wiwik. 2007. Thitonia Diversifolia Sumber Pupuk Hijau bahan organik tanaman sayuran. Jurnal Penelitian Tanah Vol.29, hal 5

Haryanto ET, Suhartini E, Rahayu dan Sunarjo 2006. Sawi dan selada Penebar Swadaya Jakarta.

Klaudya HS. Penggunaan Ampas Teh sebagai Media Tanam, 2017 Yogyakarta

Kristina NN, Syahid SF. 2012. Pengaruh Air Kelapa Muda terhadap muliplikasi tundas Produksi Rimpang, dan Kandungan Temulawak di lapangan. Jurnal Litri.

Lahadassy J, AM Mulyati, AH Sanaba. 2007. Pengaruh Konsentrasi Pupuk Organik Padat Daun Terhadap Tanaman Sawi Jurnal Agrisistem Palu Sulawesi Tengah 3 (6): 51 - 55.

Lingga P, Marsono. 2007. Petunjuk Penggunaan Pupuk Edisi Revisi Penebar Swadaya. Jakarta.

Nugraha MY. 2010. Kajian Penggunaan PupukOrganik Dan Jenis Pupuk N Terhadap hasil tanaman sawi (Brassica Junea L). Pada tanah Litosol gemolong. Skripsi Universitas Surakarta.

Rika. 2015. Pertumbuhan dan Pembungaan Krisan Pada berbagai Konsentrasi Air kelapa dan Vitamin B1. Skripsi Universitas Hassanuddin Makassar.
Rukmana R. 1994. Bertanam Petsai dan Sawi. Penerbit Kanisius. Yogyakarta.

Siswandi. 2013. Uji Hasil Tanaman Sawi Pada Berbagai Media Tanam secara Hidroponik. Jurnal Innofarm Vol.II, No.1, 44-45.

Sunarjono HH. 2007. Bertanam 30 Jenis Sayuran, Penebar Swadaya Jakarta

Slamet W. 2005. Pengaruh dosis pemupukan kompos ampas teh terhadap produksi jerami jagung manis (Zea mays S). Jurnal of Indonesian Tropical Animal dan Agriculture 30 (1) : 47-52.

Triadiati AA, Pratama dan Abdulrachman. 2012. Pertumbuhan Dan Efisiensi Penggunaa Nitrogen Pada Padi (Oriza Stiva L.) Dengan Pemberian Pupuk Urea Berbededa. Buletin Anatomi Dan Fisiologi 9 (2): 1- 14

Trinata HY. 2015. Pengaruh kompos campur Ampas Teh dan kotoran sapi terhadap ketersediaan air tanha pada tanaman sawi (Brassica Junea L). Skripsi Unversitas Brawijaya Malang.

Widyanti. 2008. Pengaruh Pemberian Kompos Ampas Teh terhadap Sifat Fisik, Kimia Tanah dan Pertumbuhan Tanaman Jagung pengaruh pemberian kompos ampas teh terhadap pertumbuhan tanaman jagung.

Yusnida B. 2006. Pengaruh Pemberian Giberelin (GA3) Dan Air Kelapa terhadap Perkecambahan bahan biji Angrek Bulan (Phalaenopsis Ambilis BL.www Biologifkip.ac.id.karya pemberian Giberelin.diakses 12 November 2010.

Zuchrochus S. 2017. Pertumbuhan Tanaman Sawi Hijau dengan pemberian kompos bahan organik; Universitas Yogyakarta 3(1) 39-46. 